\title{
Potensi Produksi Nira Enau (Arenga pinnata Merr) di Kec. Bukik Barisan Kabupaten Limapuluh Kota
}

\section{Potential Production of Nira Enau (Arenga pinnata Merr) at Bukik Barisan Districts, Limapuluh Kota Regency}

\author{
Trisia Wulantika ${ }^{1)}$ \\ Department of Cultivation Horticulture, Polytechnic of Agriculture State \\ Payakumbuh, Sumatera Barat, Indonesia
}

Email: wulan_trisia@ymail.com

\begin{abstract}
How to Cite :
Wulantika T. (2020). Potential Production of Nira Enau (Arenga Pinnata merr) at Bukik Barisan Districs, Limapuluh Kota Regency. Sinta Journal, 1(1), 01-06.DOI : https://doi.org/13.11114/sinta.1.x.x1-x2
\end{abstract}

\section{ARTICLE HISTORY \\ Received [2020-02-18] \\ Revised [2020-02-23] \\ Accepted [2020-05-16] \\ KEYWORDS \\ sugar palm plants, nira, sugar content}

This is an open access article under the $C C$ BY-SA license

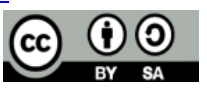

\begin{abstract}
ABSTRAK
Nira adalah cairan yang keluar dari mayang bunga jantan yang diperoleh dengan cara disadap dan memiliki rasa manis. Nira enau dapat digunakan untuk pembuatan gula merah, gula semut aren, tuak dan bahan baku pembuatan bioetanol. Kecamatan Bukik Barisan merupakan salah satu kecamatan di Kab.Limapuluh Kota dengan luas lahan Enau cukup besar yaitu sebesar $95 \mathrm{Ha}$. Penelitian ini telah dilaksanakan pada bulan Januari-April 2018 di 4 Kenagarian di Kec.Bukik Barisan dengan metode purposive sampling dan data dianalisis secara deskriptif dengan menggunakan metode statistik sederhana. Berdasarkan penelitian yang telah dilaksanakan diperoleh hasil, Kenagarian Banjar Lawas memiliki ratarata produksi nira perhari lebih tinggi dibanding 3 Kenagarian lain yaitu sebesar 8,29 Liter/hari, sedangkan untuk pengukuran kadar gula, rata rata aksesi enau di Kenagarian Koto Tangah memiliki kadar gula lebih tinggi dibanding Kenagarian lain, yaitu sebesar 15,75 Brix. Tanaman Enau di Kecamatan Bukik Barisan sangat potensial untuk dikembangkan karena memiliki potensi produksi per hari yang cukup tinggi seiring dengan kandungan gula yang juga tinggi.
\end{abstract}




\section{ABSTRACT}

Nira is a fluid that comes out of the male flower that is obtained by means of tapped and has a sweetness. Nira Enau can be used for the manufacture of brown sugar, sugar ant palm, Tuak and bioethanol making raw materials. Bukik Barisan Subdistrict is one of the sub-districts of Kab.Limapuluh Kota with the area of Enau is large enough to be $95 \mathrm{Ha}$. This study has been implemented in January-April 2018 at 4 Kenagarian in the Kec. Bukik Barisan with purposive sampling method and data analyzed descriptively using simple statistical methods. Based on the research that has been carried out results, Kenagarian Banjar Lawas has an average production of nira per day higher than 3 other Kenagarian is 8.29 Liter/day, while for the measurement of sugar content, the average accession Enau in the Kenagarian Koto Tangah has a higher sugar level than other Kenagarian, namely 15.75 Brix. Enau plant in Bukik Barisan Sub District is very potential to be developed because it has a high production potential per day that is quite high along with the sugar content which is also higher.

\section{PENDAHULUAN}

Nira adalah cairan yang dihasilkan dan dikeluarkan dari jenis palm seperti aren, siwalan, kelapa, nipah, sagu, kurma. Nira enau adalah cairan yang keluar dari mayang bunga jantan yang diperoleh dengan cara disadap dan memiliki rasa manis. Dalam keadaan segar nira berasa manis, berbau khas nira dan tidak berwarna. Nira aren mengandung beberapa zat gizi antara lain karbohidrat, protein, lemak dan mineral. Rasa manis pada nira disebabkan kandungan karbohidratnya mencapai $11,28 \%$. Nira yang baru menetes dari tandan bunga mempunyai pH sekitar 7 ( $\mathrm{pH}$ netral), akan tetapi pengaruh keadaan sekitarnya menyebabkan nira aren mudah terkontaminasi dan mengalami fermentasi sehingga rasa manis pada nira aren cepat berubah menjadi asam ( $\mathrm{pH}$ menurun).

Nira enau berguna untuk pembuatan gula merah yang digunakan dalam pembuatan makanan, selain itu nira juga dapat dibuat tuak dan cuka. Alkohol yang dihasilkan secara ilmiah dikenal dengan nama etanol, nira dapat diubah menjadi bioetanol dengan bantuan fermentasi oleh bakteri ragi (Saccharomyces cereviseae) dimana kandungan gula (sukrosa) pada nira dikonversi menjadi glukosa kemudian menjadi etanol. Nira enau memiliki kelebihan dibandingkan dengan bahan baku bioetanol lainnya seperti singkong dan jagung karena hanya melalui satu tahap saja yaitu tahap fermentasi, sedangkan bioetanol yang berasal dari tanaman berpati lainnya memerlukan tahap hidrolisis ringan (sakarifikasi) untuk merubah polimer pati menjadi gula sederhana. Beberapa faktor yang mempengaruhi komposisi nira diantaranya umur tanaman, varietas tanaman, iklim, keadaan tanah, pengairan , pemupukan dan kesehatan tanaman. 
Berdasarkan data BPS Kab.Limapuluh Kota, 2018, Kecamatan Bukik Barisan merupakan Kecamatan dengan luas lahan Enau terbesar yaitu sebesar $95 \mathrm{Ha}$. Kecamatan Bukik Barisan terdiri atas 5 Kenagarian yaitu Sungai Naniang, Baruah Gunuang, Koto Tangah, Mahat dan Banjar Lawas, dari 5 Kenagarian tersebut hanya Kenagarian Mahat yang tidak menjadi lokasi penelitian dikarenakan di daerah tersebut sangat jarang dilakukan pengolahan terhadap tanaman enau.

Mengingat luasnya lahan enau di Kenagarian Sungai Naniang maka perlu dilakukan penelitian terhadap potensi produksi nira enau yang meliputi produksi perhari dan kandungan kadar gula nira sebagai faktor dasar untuk dapat digunakan sebagai landasan penelitian selanjutnya. Mengingat betapa potensialnya nira enau ini untuk pembuatan gula merah, gula semut aren ataupun bahan baku pembuatan bioetanol.

\section{METODE PENELITIAN}

Penelitian dilakukan di 4 Kenagarian di Kec.Bukik Barisan (Kenagarian Sungai Naniang, Baruah Gunuang, Koto Tangah, Banjar Lawas) pada bulan Januari - April 2018. Bahan yang digunakan adalah tanaman enau yang berumur lebih dari 8 tahun dan sudah memasuki fase generatif. Penelitian dilakukan di 4 Kenagarian di Kec.Bukik Barisan (Kenagarian Sungai Naniang, Baruah Gunuang, Koto Tangah, Banjar Lawas) pada bulan Januari - April 2018 dengan Metode Purposive sampling dan data dianalisis secara deskriptif dan menggunakan metode statistik sederhana. Sampel yang digunakan dalam penelitian ini adalah 40 aksesi tanaman enau dengan pengamatan produksi nira selama 1 bulan.

\section{HASIL DAN PEMBAHASAN}

Nira enau dihasilkan dari penyadapan tandan bunga jantan. Jika yang disadap tandan bunga betina, maka akan diperoleh nira yang tidak memuaskan baik dari segi kuantitas maupun kualitasnya. Pengamatan dilakukan terhadap produksi dan kadar gula nira. Berdasarkan penelitian yang telah dilakukan, diperoleh produksi nira yang berbeda disetiap aksesi, namun perbedaannya tidak terlalu signifikan.

Hasil sadapan nira dipengaruhi oleh beberapa faktor, wawancara yang dilakukan dengan Bapak Hendri (37 tahun) penyadap nira di Kenagarian Koto Tangah, beliau menyatakan bahwa beberapa faktor yang mempengaruhi hasil sadapan nira ana, seperti cuaca, beliau menyatakan bahwa produksi nira akan berkurang atau lebih sedikit bila cuaca panas dibandingkan bila cuaca hujan, kemudian untuk faktor lain seperti hama tupai, musang yang menghisap nira enau. Selanjutnya keahlian dalam mengiris dan memukul-mukul mayang bunga jantan enau, karena pemukulan mayang bunga jantan termasuk dalam kegiatan persiapan penyadapan. Kegiatan persiapan penyadapan merupakan kegiatan yang sangat penting agar dapat memperoleh nira yang cukup banyak dan penyadapan dapat lebih lama dilakukan. Rata-rata produksi nira enau perhari yang sudah diamati selama 1 bulan dapat dilihat pada Tabel 1 , sedangkan kadar gula nira enau dapat dilihat pada Tabel 2.

Berdasarkan Tabel 1 terlihat bahwa Kenagarian Banjar Lawas memiliki rata rata produksi yang lebih besar dibanding 3 Kenagarian lain dengan rata rata produksi perhari sebesar 8,29 Liter/hari.

Berdasarkan Tabel 2 terlihat bahwa aksesi enau di Kenagarian Koto Tangah memiliki kandungan gula lebih tinggi dibanding aksesi pada 3 Kenagarian lain, yaitu sebesar 15,75 brix. Pengamatan kadar gula dilakukan secepat mungkin. Menurut 
Marsigit (2005) nira enau mudah mengalami kerusakan karena dipengaruhi oleh kondisi lingkungan selama penyadapan dan pengangkutan ke tempat pengolahan serta akibat proses fermentasi, oleh karena itu analisis kadar gula harus dilakukan secepat mungkin. Pada keseluruhan aksesi, ditemui 3 variasi warna nira enau yaitu kuning terang, kuning gelap dan putih. Pengujian terhadap kadar gula diperoleh hasil bahwa kadar gula nira yang berwarna kuning lebih tinggi dibanding nira yang berwarna putih. Wawancara terhadap 4 penyadap aren di 4 Nagari yaitu bapak Hendri (37 tahun), bapak Isar (60 tahun), bapak Andrianto (38) dan bapak Sarawik (60 tahun), beliau menyatakan bahwa nira enau yang bagus adalah yang berwarna kuning, sedangkan nira enau yang berwarna putih kualitas gula aren yang dihasilkan kurang bagus, untuk warna nira dapat dilihat pada Gambar 1.

Tabel 1. Rata-rata produksi nira enau perhari di Kec.Bukik Barisan

Table 1. Average production per day in Kec. Baruk Barisan

\begin{tabular}{lc}
\hline Aksesi Enau Di Kec.Bukik Barisan & $\begin{array}{c}\text { Rata-rata Produksi Nira Per Hari } \\
\text { Selama 1 Bulan (Liter) }\end{array}$ \\
\hline Kenagarian Sungai Naniang & 7,34 \\
Kenagarian Baruah Gunuang & 7,54 \\
Kenagarian Koto Tangah & 7,85 \\
Kenagarian Banjar Lawas & 8,29 \\
\hline
\end{tabular}

Tabel 2. Pengujian kadar gula enau di Kec.Bukik Barisan

Table 2. Testing of palm sugar levels in Kec. Baruk Barisan

\begin{tabular}{lc}
\hline Aksesi Enau Di Kec.Bukik Barisan & Kadar Gula (Brix) \\
\hline Kenagarian Sungai Naniang & 13,63 \\
Kenagarian Baruah Gunuang & 14,09 \\
Kenagarian Koto Tangah & 15,75 \\
Kenagarian Banjar Lawas & 15,20 \\
\hline
\end{tabular}




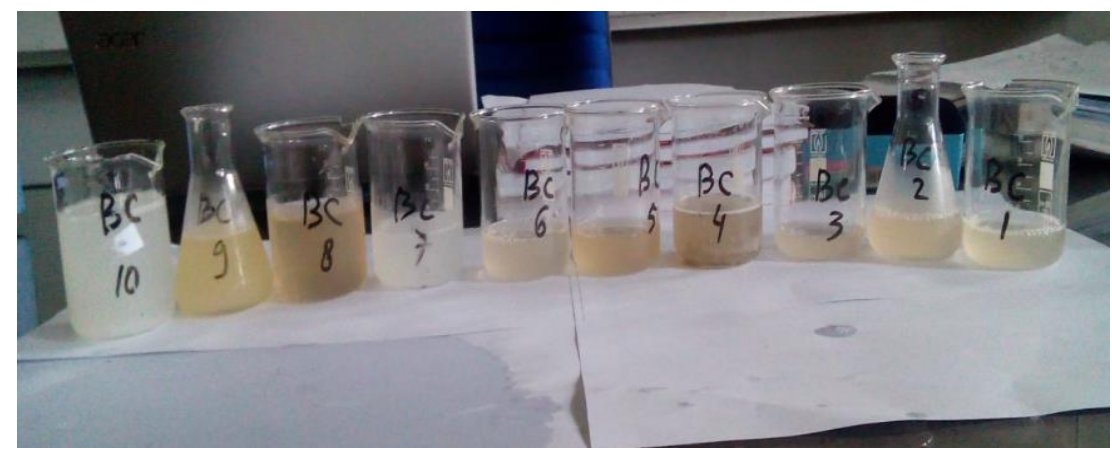

Gambar 1. Warna nira enau di Kec.Bukik Barisan

Figure 1. The color of palm sugar in Kec.Bukik Barisan

Keterangan : Nira yang berwarna kuning terang $(1,2,3,6)$, Nira yang berwarna kuning gelap $(4,5,8,9)$, Nira yang berwarna putih $(7,10)$

Berdasarkan penelitian yang telah dilakukan terhadap potensi produksi nira enau di Kecamatan Bukik Barisan dapat dilihat bahwa ke 4 Kenagarian yang diteliti sangat potensial untuk dikembangkan mengingat produksi nira yang besar dari 5 liter/hari dan kadar gula diatas 10 brix.

\section{KESIMPULAN DAN SARAN}

\section{Kesimpulan}

Dari penelitian yang telah dilakukan dapat disimpulkan bahwa tanaman enau di Kecamatan Bukik Barisan sangat potensial untuk dikembangkan, karena memiliki potensi produksi nira yang tinggi dan kandungan kadar gula yang tinggi. Aksesi enau di Kenagarian Banjar Lawas memiliki rata-rata produksi nira perhari lebih tinggi dibanding 3 Kenagarian lain yaitu sebesar 8,29 Liter/hari, sedangkan untuk pengukuran kadar gula, aksesi enau di Kenagarian Koto Tongah memiliki kadar gula lebih tinggi dibanding 3 Kenagarian lain, yaitu sebesar 15,75 Brix. 


\section{UCAPAN TERIMA KASIH}

e-ISSN : -

Ucapan terima kasih penulis ucapkan kepada semua pihak yang telah membantu dalam penyelesain penelitian ini yang tidak dapat disebutkan satu persatu, semoga dibalasi Allah dengan pahala setimpal.aamiin ya rabbal alamin.

\section{DAFTAR PUSTAKA}

Badan Pusat Statistik. 2018. KabupatenLima Puluh Kota dalam Angka 2018.Sarilamak.

Lempang, M., Mangopang, A.D. 2012. Efektivitas Nira Aren Sebagai Bahan Pengembang Adonan Roti. Jurnal Penelitian Kehutanan Wallacea1 (1): 26 - 35.

Wulantika,T.2018. Keragaman Fenotipe Aren (Arenga Pinnata) di Kecamatan Bukit Barisan Kabupaten Limapuluh Kota. Jurnal Ilmiah Pertanian, Vol. 15, No. 2, Pebruari 2019. 